\title{
EFEKTIVITAS TERAPI KOMBINASI MASASE FRIRAGE DAN LATIHAN PNF TERHADAP PEMULIHAN CEDERA PANGGUL
}

\author{
Davit Firmanda Hernowo ${ }^{1}$, Rachmah Laksmi Ambardini ${ }^{1}$ \\ ${ }^{1}$ Fakultas Ilmu Keolahragaan, Universitas Negeri Yogyakarta, Jl. Colombo No. 1, Karangmalang Depok, \\ Sleman, Yogyakarta, Indonesia \\ 12603141009@student.uny.ac.id,rachmah_la@uny.ac.id
}

\begin{abstract}
Abstrak
Cedera adalah kelainan atau gangguan yang terjadi pada anggota tubuh yang menyebabkan timbulnya keluhan seperti, nyeri, panas, merah, bengkak, dan tidak dapat berfungsi baik pada otot, tendon, ligamen, persendian maupun tulang yang terjadi akibat aktivitas yang berulang, berlebihan maupun kecelakaan. Panggul merupakan salah satu bagian persendian yang sering digunakan manusia melakukan aktivitas sehari-hari, oleh karena itu akan memiliki persentase untuk dapat terjadi cedera. Masase terapi ataupun stretching merupakan salah satu upaya yang dapat dilakukan untuk mengurangi keluhan cedera. Tujuan penelitian ini untuk mengetahui tentang efektivias terapi kombinasi Frirage dan terapi latihan PNF terhadap pemulihan cedera panggul. Metode penelitian menggunakan penelitian pra eksperimen dengan desain satu kelompok dengan tes awal dan tes akhir (one-group pretest-posttest design). Penelitian ini dilakukan di klinik terapi FIK UNY pada tanggal 14 sampai dengan 27 September 2017. Populasi penelitian ini adalah pasien laki-laki di klinik terapi FIK UNY pada bulan Agustus 2017. Sampel dalam penelitian ini sebanyak 15 subjek diperoleh dengan menggunakan purposive sampling. Hasil penelitian pada range of motion (ROM) secara keseluruhan sebelum dan sesudah perlakuan menunjukkan nilai signifikansi ( $\mathrm{p}<0,05$ ), dengan efektivitas sebesar 6,60\% untuk fleksi, 26,85\% untuk ekstensi, 28,23\% untuk abduksi, 10,74\% untuk adduksi, 5,16 untuk medial rotasi, dan 6,77\% untuk lateral rotasi, pada nyeri secara keseluruhan sebelum dan sesudah perlakuan menunjukkan nilai signifikansi ( $\mathrm{p}<0,05)$, dengan efektivitas sebesar 51,13\%. dan pada fungsi gerak secara keseluruhan sebelum dan sesudah perlakuan menunjukkan nilai signifikansi (p. <0,05), dengan efektivitas sebesar 72,10\% untuk jalan, 73,33\% untuk duduk berdiri, 50,53\% untuk berdiri satu kaki. Simpulan penelitian, terapi kombinasi masase frirage dan terapi latihan PNF efektif terhadap pemulihan ROM, nyeri dan fungsi gerak cedera panggul pasien Klinik Terapi FIK UNY.
\end{abstract}

Kata Kunci: Cedera Panggul, Terapi Masase Frirage, Terapi Latihan PNF.

\section{EFFECTIVENESS OF FRIRAGE MASSAGE THERAPY THERAPY AND PNF EXERCISES ON PELVIC INJURY RECOVERY}

\begin{abstract}
Injury is a disorder or disorder that occurs in a limb that causes complaints such as pain, heat, redness, swelling, and can not function well in muscles, tendons, ligaments, joints or bones that occur due to repetitive, excessive activity or accidents. Pelvis is one part of a joint that is often used by humans to carry out daily activities, therefore it will have a percentage of injury to occur. Massage therapy or stretching is one effort that can be done to reduce injury complaints. The purpose of this study was to find out about the effectivity of Frirage combination therapy and PNF exercise therapy on pelvic injury recovery. The research method uses pre-experimental research with one group design with initial tests and final tests (one-group pretest-posttest design). The research was conducted at the UNY FIK therapy clinic on 14 to 27 September 2017. The population of this study was male patients at the UNY FIK therapy clinic in August 2017. The samples in this study were 15 subjects obtained using purposive sampling. The results of the study on the range of motion (ROM) as a whole before and after treatment showed a significance value ( $p<0.05)$, with an effectiveness of $6.60 \%$ for flexion, $26.85 \%$ for extension,
\end{abstract}


$28.23 \%$ for abduction, $10.74 \%$ for adduction, 5.16 for medial rotation, and $6.77 \%$ for lateral rotation, the overall pain before and after treatment showed a significance value ( $p<0.05)$, with an effectiveness of 51.13\%. and the overall motion function before and after treatment showed a significance value ( $p$. $<0.05$ ), with an effectiveness of $72.10 \%$ for the road, $73.33 \%$ for sitting standing, 50.53\% for standing on one foot. Conclusions of the study, combination massage therapy and PNF exercise therapy are effective for recovery of ROM, pain and pelvic injury function of patients at the Therapy Clinic of Sport Science Faculty UNY.

Keywords: Pelvic Injury, Frirage Massage Therapy, PNF Exercise Therapy

\section{PENDAHULUAN}

Cedera pada atlet dan orang biasa sering terjadi dikarenakan olahraga berat. Hal tersebut terjadi karena pada saat melakukan olahraga berat tidak melakukan pemanasan terlebih dahulu, sehingga beresiko cedera. Banyak sekali jenis cedera yang sering dialami oleh banyak orang karena tidak melakukan pemanasan dengan benar pada saat olahraga berat. Hal ini sering terjadi saat melakukan latihan beban, latihan di lapangan, atau pertandingan olahraga. Cedera yang sering terjadi yaitu cedera engkel, cedera lutut, cedera bahu, dan cedera panggul.

Khusus untuk cedera panggul dapat terjadi karena beberapa gerakan yang membuat panggul bekerja lebih sering seperti pada olahraga loncat jauh. Bukan hanya itu, cedera panggul juga bisa terjadi pada saat melakukan kegiatan sehari-hari. Kebiasaan mengangkat beban tanpa awalan dan dengan gerakan tiba-tiba dapat membuat sendi panggul kita menjadi sakit. Cedera panggul dapat terjadi selain dari aktivitas olahraga dan kegiatan sehari-hari disebabkan karena kecelakan ataupun jatuh dari tempat duduk.

Ilmu kedokteran klinis seperti fisioterapi sekarang ini banyak diminati sebagai pengobatan alternatif untuk menangani keluhan cedera olahraga maupun karena aktivitas sehari-hari.Menurut survey work-related illnesses pada tahun 1995 di Inggris menunjukkan bahwa dari perkiraan 43.000 pekerja terjadi gangguan muskuloskletal dengan rincian kasus back pain pada 27.000 pekerja, upper limb injury atau keluhan pada leher 10.000 pekerja, dan keluhan pada lower limb injury 11.000 pekerja (Bone and Palmer, 2002:441). Di Indonesia, persentase keluhan nyeri pinggang pada suatu rumah sakit di Surabaya sebesar 45,5\% dari 46 orang yang diteliti. Berbagai faktor dikaitkan sebagai penyebab nyeri pinggang, yaitu faktor beban kerja fisik berat dan posisi kerja yang buruk (Lusianawaty, 2013:2).

Sampai saat ini banyak sekali terapi untuk memulihkan cedera pada sendi atau dislokasi. Diantaranya adalah terapi masase frirage, trigger point massage, dan deep tissue massage yang diyakini bisa mengurangi gejala cedera bahu bahkan mengembalikan keposisi semula. Salah satunya yang sudah dilakukan penelitian adalah terapi masase frirage yang bisa menciptakan relaksasi yang lebih dalam dan penyembuhan cedera ringan berupa otot dan kesleo pada persendian secara umum (Graha dan Priyonoadi, 2009: 16).

Teknik masase (masase frirage) pada rehabilitasi cedera yang digunakan yaitu teknik masase berupa gerusan (friction), gosokan (effleurage) menggunakan ibu jari dan penarikan (traksi) serta pengembalian sendi pada posisinya (reposisi). Masase frirage dilakukan dengan posisi telentang karena untuk mempermudah proses dalam penanganan dan memudahkan berkomunikasi kepada pasien saat melakukan manipulasi juga merileksasikan otot (Graha. A.S., 2009: 14).

Dari sisi aktivitas fisik, ketika seseorang mengalami cedera pada salah satu anggota tubuh, maka tidak akan mengembalikan kekuatan sendi dan fungsi panggul seperti sedia kala. Salah satu pilihan yang harus dilakukan untuk membuat sendi panggul menjadi kuat lagi adalah dengan melakukan terapi latihan, salah satu jenis terapi latihan adalah PNF. Terapi latihan PNF merupakan terapi dengan memberikan rangsangan pada proprioseptor sebagai cara untuk meningkatkan kebutuhan mekanisme neuromuscular dengan dibuat lebih mudah. 
Dari pengamatan yang dilakukan peneliti di Klinik Terapi FIK UNY, (1) pasien laki-laki klinik terapi UNY yang mengalami cedera panggul sebanyak 147 dari 637 pasien yang datang. Jadi sekitar 23\% dari keseluruhan pasien klinik terapi UNY mengalami cedera panggul, (2) dari sekian pasien cedera panggul yang datang, ada 35 pasien yang datang lagi pada bulan yang sama dan cedera yang sama karena cedera yang mereka alami kambuh. Hal ini terjadi karena mereka menggunakan sendi panggul terlalu berlebihan sebelum dilatih dengan menggunakan terapi latihan PNF, (3) Masyarakat luas juga belum tahu banyak tentang terapi masase Frirage terapi latihan PNF yang sangat berguna untuk pemulihan cedera panggul.

\section{METODE}

Penelitian ini merupakan penelitian eksperimen dengan desain satu kelompok dengan tes awal dan tes akhir (the one-group pretest-posttest design) (Sugiyono, 2008: 74). Populasi penelitian ini adalah pasien laki-laki klinik terapi FIK UNY pada bulan Agustus 2017 yang datang lebih dari sekali untuk cedera yang sama sebanyak 35 orang.

Teknik sampel yang digunakan dalam penelitian ini adalah purposive sampling yaitu teknik penentuan sampel dengan pertimbangan tertentu (Sugiyono, 2015: 124). Sampel penelitian ini adalah pasien laki-laki klinik terapi FIK UNY yang mengalami cedera panggul sebanyak 15 orang dengan kriteria kelompok umur 20-35 tahun, mengalami cedera panggul derajat ringan dengan keluhan sedikit nyeri dan gangguan fungsi sendi, dan bersedia diberi perlakuan terapi kombinasi masase frirage dan latihan PNF. Instrumen penelitian ini menggunakan goniometer untuk mengukur ROM sendi Panggul pada saat pretest dan posttest.

Teknik pengumpulan data pada penelitian ini adalah data yang diperoleh dengan menggunakan pengukuran goniometer dan Visual Analog Scale pada sendi panggul dari populasi pasien Klinik Terapi FIK UNY.

\section{HASIL DAN PEMBAHASAN}

Secara keseluruhan, hasil dalam penelitian ini dapat disimpulkan bahwa: Terapi kombinasi masase frirage dan latihan proprioceptive neuromuscular fasilitation (PNF) dapat memulihkan range of motion cedera panggul pasien Klinik Terapi FIK UNY dengan efektivitas sebesar $6,60 \%$ untuk fleksi, 26,85\% untuk ekstensi, 28,23\% untuk abduksi, 10,74\% untuk adduksi, 5,16 untuk medial rotasi, dan $6,77 \%$ untuk lateral rotasi.

Tabel 1. Range of motion

\begin{tabular}{|c|c|c|c|c|}
\hline \multirow{2}{*}{ Data } & Pretest & Posttest & \multirow{2}{*}{ Peningkatan } & Persentase \\
\cline { 2 - 3 } & Mean & Mean & & \\
\hline Fleksi & 109.07 & 116.27 & 7.2 & 6.60 \\
\hline Ekstensi & 21.60 & 27.40 & 5.8 & 26.85 \\
\hline Abduksi & 21.00 & 26.93 & 5.93 & 28.23 \\
\hline Adduksi & 38.53 & 42.67 & 4.14 & 10.74 \\
\hline Medial Rotasi & 37.40 & 39.33 & 1.93 & 5.16 \\
\hline Lateral Rotasi & 38.40 & 41.00 & 2.6 & 6.77 \\
\hline
\end{tabular}

Dari seluruh pemberian perlakuan, baik itu fleksi, ekstensi, abduksi, adduksi, medial rotasi, dan lateral rotasi, dilakukan sebelum dan sesudah perlakuan, dengan nilai sig. $<0,05$ (seperti terlihat pada Tabel. 2.), maka menurut kriteria pengujian hipotesis, H0 diterima. Artinya, pemberian perlakuan sebelum dan sesudah terdapat perbedaan yang signifikan. 
MEDIKORA, Vol. XVIII No. 2 Oktober 2019 - 89

Davit Firmanda Hernowo, Rachmah Laksmi Ambardini

Tabel 2. Nilai signifikansi Range of motion

\begin{tabular}{|l|l|c|c|c|}
\hline \multicolumn{2}{|c|}{ Range OfMotion(ROM) } & t & df & $\begin{array}{c}\text { Sig. (2- } \\
\text { tailed) }\end{array}$ \\
\hline Pair 1 & Sebelum_Fleksi - Sesudah_Fleksi & -6.441 & 14 & .000 \\
\hline Pair 2 & Sebelum_Ekstensi - Sesudah_Ekstensi & -6.900 & 14 & .000 \\
Pair 3 & Sebelum_Abbduksi - Sesudah_Abbduksi & -5.634 & 14 & .000 \\
\hline Pair 4 & Sebelum_Adduksi - Sesudah_Adduksi & -4.863 & 14 & .000 \\
\hline Pair 5 & Sebelum_Medial_Rotasi - Sesudah_Medial_Rotasi & -3.477 & 14 & .004 \\
Pair 6 & Sebelum_Lateral_Rotasi - Sesudah_Lateral_Rotasi & -2.796 & 14 & .014 \\
\hline
\end{tabular}

Analisa:

H0 : Tidak ada pengaruh terapi kombinasi Masase Frirage dan Terapi latihan PNF terhadap perbaikan ROM sendi panggul

H1 : Ada pengaruh terapi kombinasi Masase Frirage dan Terapi latihan PNF terhadap perbaikan ROM sendi panggul

Terapi kombinasi masase frirage dan latihan proprioceptive neuromuscular fasilitation (PNF) dapat menurunkan derajat nyeri cedera panggul pasien Klinik Terapi FIK UNY dengan efektivitas sebesar $51,13 \%$.

Tabel 3. Nilai signifikansi derajat nyeri cedera panggul

\begin{tabular}{|l|l|c|r|r|}
\hline \multicolumn{2}{|c|}{ Nyeri } & t & df & $\begin{array}{c}\text { Sig. (2- } \\
\text { tailed) }\end{array}$ \\
\hline Pair 3 & Sebelum_Nyeri - Sesudah_Nyeri & 5.843 & 14 & .000 \\
\hline
\end{tabular}

Analisa:

H0 : Tidak ada pengaruh terapi Masase Frirage dan Terapi latihan PNF terhadap perbaikan tanda sendi panggul

H1 : Ada pengaruh terapi Masase Frirage dan Terapi latihan PNF terhadap perbaikan tanda sendi panggul

Kriteria Keputusan:

H0 diterima apabila nilai $\mathrm{p}$ (sig.) $>0.05$

H0 ditolak apabila nilai p (sig.) $<0.05$

Karena nilai sig. $<0,05$ maka menurut kriteria pengujian hipotesis, $\mathrm{H}_{0}$ diterima. Artinya, pemberian perlakuan sebelum dan sesudah terdapat perbedaan yang signifikan.

Terapi kombinasi masase frirage dan latihan proprioceptive neuromuscular fasilitation (PNF) dapat meningkatkan fungsi gerak cedera panggul pasien Klinik Terapi FIK UNY dengan efektivitas sebesar 72,10\% untuk jalan, 73,33\% untuk duduk berdiri, 50,53\% untuk berdiri satu kaki.

Tabel 4. Fungsi gerak.

\begin{tabular}{|c|c|r|c|c|}
\hline \multirow{2}{*}{ Gerak } & Pretest & \multicolumn{1}{|c|}{ Posttest } & peningkatan & persentase \\
\cline { 2 - 5 } & Mean & Mean & pening \\
\hline Jalan & 5.27 & 9,07 & 3.8 & 72,10 \\
\hline Duduk Berdiri & 6.00 & 10,40 & 4.4 & 73,33 \\
\hline Berdiri Satu Kaki & 6.53 & 9,86 & 3.3 & 50,53 \\
\hline
\end{tabular}

Berdasarkan hasil pengujian yang diperoleh bahwa nilai signifikansi perlakuan sebelum dan sesudah pada fungsi gerak jalan, duduk berdiri dan berdiri satu kaki sebesar 0,000. Karena 
nilai sig. $<0,05$ maka menurut kriteria pengujian hipotesis, H0 diterima. Artinya, pemberian perlakuan sebelum dan sesudah terdapat perbedaan yang signifikan.

Tabel 5. Nilai signifikansi fungsi gerak pada cedera panggul.

\begin{tabular}{|c|c|c|c|}
\hline \multicolumn{1}{|c|}{ Fungsi gerak } & $\mathrm{t}$ & $\mathrm{Df}$ & $\begin{array}{c}\text { Sig. (2- } \\
\text { tailed) }\end{array}$ \\
\hline Pair 1 Pretest_Jalan - Prosttest_Jalan & -12.192 & 14 & .000 \\
\hline Pair 2 Pretest_Duduk_Berdiri - Posttest_Duduk_Berdiri & -10.687 & 14 & .000 \\
\hline Pair 3 Pretest_BerdiriSatuKaki - Posttest_BerdiriSatuKaki & -6.070 & 14 & .000 \\
\hline
\end{tabular}

\section{Efektivitas terapi kombinasi masase frirage dan terapi latihan PNF dalam pemulihan rom cedera panggul pasien klinik terapi FIK UNY}

Berdasarkan analisis data diketahui bahwa terapi kombinasi masase Frirage dan latihan PNF efektif dalam perbaikan ROM cedera panggul (fleksi, ekstensi, abduksi, adduksi, medial rotasi dan lateral rotasi) secara keseluruhan memiliki nilai sig. $<0,05$ seperti pada Tabel 18 . Hal ini terjadi karena perlakuan terapi kombinasi masase Frirage dan latihan PNF mempunyai efek fisiologis peningkatan mobilitas sendi dan memperkuat otot yang menyokong dan melindungi sendi, nyeri, dan kaku sendi (Ambardini, 2006: 30). Peregangan dengan metode PNF merupakan metode peregangan yang bagus untuk cedera pada sendi sehingga bisa memperoleh hasil yang maksimal (Juliantine, 2011: 12). Penerapan latihan PNF pada sendi panggul dapat meregangkan sekaligus menguatkan otot pada sendi panggul. Pemberian terapi latihan pada cedera setelah mendapatkan terapi masase dan istirahat selama tiga (3) hari dan mendapatkan terapi latihan selama enam (6) kali akan meningkatkan peregangan pada sendi sekaligus menguatkan otot pada sendi tersebut (Graha, 2009).

\section{Efektivitas terapi kombinasi masase frirage dan terapi latihan PNF dalam menurunkan derajat nyeri cedera panggul pasien klinik terapi FIK UNY}

Berdasarkan analisis data diketahui bahwa ada pengaruh terapi latihan PNF pasca cedera panggul terhadap nyeri sendi panggul memiliki nilai sig. $<0,05$ seperti pada Tabel 19. Hal ini terjadi karena perlakuan terapi latihan mempunyai efek fisiologis peningkatan mobilitas sendi dan memperkuat otot yang menyokong dan melindungi sendi, nyeri, dan kaku sendi (Ambardini, 2006: 30). Berdasarkan analisis data diketahui bahwa ada pengaruh terapi latihan PNF pasca cedera panggul terhadap tanda sendi panggul panas memiliki nilai sig. $>0,05$ seperti pada Tabel 19. Penerapan latihan PNF pada sendi panggul dapat meregangkan sekaligus menguatkan otot pada sendi panggul. Pemberian terapi latihan pada cedera setelah mendapatkan terapi masase dan istirahat selama tiga (3) hari dan mendapatkan terapi latihan selama enam (6) kali akan meningkatkan peregangan pada sendi sekaligus menguatkan otot pada sendi tersebut (Graha, A.S., 2009).

\section{Efektivitas terapi kombinasi masase frirage dan terapi latihan PNF dalam meningkatkan fungsi gerak cedera panggul pasien klinik terapi FIK UNY}

Berdasarkan analisis data diketahui bahwa ada pengaruh terapi latihan PNF pasca cedera panggul terhadap perbaikan fungsi gerak sendi panggul (berjalan, duduk berdiri, dan berdiri satu kaki) secara keseluruhan memiliki nilai sig. < 0,05 seperti pada Tabel 20. Peregangan dengan metode PNF merupakan metode peregangan yang bagus untuk cedera pada sendi sehingga bisa memperoleh hasil yang maksimal (Juliantine, 2011: 12). Pemberian terapi latihan pada cedera setelah mendapatkan terapi masase dan istirahat selama tiga (3) hari dan mendapatkan terapi latihan selama enam (6) kali akan meningkatkan peregangan pada sendi sekaligus menguatkan otot pada sendi tersebut (Graha, A.S., 2015). Hal ini terjadi karena 
MEDIKORA, Vol. XVIII No. 2 Oktober 2019 - 91

Davit Firmanda Hernowo, Rachmah Laksmi Ambardini

perlakuan terapi latihan mempunyai efek fisiologis peningkatan mobilitas sendi dan memperkuat otot yang menyokong dan melindungi sendi, nyeri, dan kaku sendi (Ambardini, 2006: 30).

\section{SIMPULAN}

Terapi kombinasi masase frirage dan latihan proprioceptive neuromuscular fasilitation (PNF) dapat memulihkan range of motion cedera panggul pasien, menurunkan derajat nyeri cedera panggul pasien dan meningkatkan fungsi gerak cedera panggul pasien secara signifikan.

\section{DAFTAR PUSTAKA}

Ambardini, R.L. (2006). Peran Latihan Fisik dalam Manajemen Terpadu Osteoartritis. Medikora. Yogyakarta: FIK UNY.

Graha, A.S. (2009). Pedoman dan Modul Terapi Masase Frirage Penatalaksanaan Terapi Masase dan Cedera Olahraga pada Engkel. Yogyakarta: Klinik Terapi Fisik UNY.

Graha, A.S., \& Priyonoadi, B. (2009).Terapi Masase Frirage. Penatalaksanaan Cedera pada Anggota Tubuh Bagian Bawah. Yogyakarta: FIK UNY.

Juliantine, T. (2011). Metode Latihan Peregangan Dinamis, Statis, Pasif, dan Kontraksi Relaksasi (PNF) Serta Klentikan. Jurnal Universitas Pendidikan Indonesia. Bandung.

Lusianawaty, T., \& Delima. (2013). Gamabran nyeri pinggang pada paramedis di beberapa rumah sakit di Jakarta. Media Litbangkes Vol. 23 No. 1, 1-7.

Sukadiyanto. (2010). Pengantar Teori dan Metodologi Melatih Fisik. Yogyakarta: FIK UNY. Sugiyono. (2009). Metode Penelitian Administrasi. Bandung: Alfabeta.

Taylor, P.M \& Taylor, D.K. (2002). Mencegah dan Mengatasi Cedera Olahraga. (Pukulal Khalib, Terjemahan). Jakarta: PT. Grafindo Persada. 